\title{
Performance and genetic parameters of economically important traits of Black Bengal goat
}

\author{
S. Faruque ${ }^{1}$, S. A. Chowdhury ${ }^{1}$, N. U. Siddiquee ${ }^{2}$ and M. A. Afroz ${ }^{3}$ \\ ${ }^{1}$ Bangladesh Livestock Research Institute, Savar, Dhaka 1341, ${ }^{2}$ Upazilla Livestock Officer, Mymensingh Sadar, \\ Mymensingh-2200 and ${ }^{3}$ Department of Animal Breeding and Genetics, Bangladesh Agricultural University, \\ Mymensingh-2202, Bangladesh
}

\begin{abstract}
A nucleus-breeding flock of selected Black Bengal goat was established in the Bangladesh Livestock Research Institute (BLRI) with the objective of conservation and improvement of the breed. A total of 120 does of different generations $(70=$ foundation stock, $45=$ First generation and $5=$ Second generation) and 20 bucks (15=Foundation stock and 5=First generation) were used to study the genetic parameters of Black Bengal goat on productive and reproductive traits. Animals were bred naturally. Goats were reared under intensive and semi-intensive management to compare performance. Birth weights of kids were $1.49 \pm 0.13$ and $1.28 \pm 0.11 \mathrm{~kg}$, respectively for intensive and semiintensive rearing system. Number of services required for each successful conception was $1.16 \pm 0.019$ with an average gestation length of $143.33 \pm 0.68$ days. Litter size increased $(P<0.001)$ linearly with parity. Average litter size of Black Bengal goat was $1.94 \pm 0.06$. Rearing system, season, parity, generation and generation $\times$ parity interaction did not affect $(P>0.05)$ the post partum estrous interval. Young females attained puberty at an age and weight of $186.02 \pm 10.52$ days and $9.4 \pm 0.52 \mathrm{~kg}$, respectively. In case of intensive rearing system it took 139 days to show $1^{\text {st }}$ heat compared to 198 days in semi-intensive rearing system. Intensive system reduced the age at $1^{\text {st }}$ kidding to $284 \pm 31.2$ days from $370 \pm 25.5$ days in semi-intensive system. The effects of parity, generation, and generation $\times$ parity interaction on kidding interval were not significant $(P>0.05)$. The average daily milk yield and lactation length was $1.088 \mathrm{~kg}$ (750g suckled milk $+338 \mathrm{~g}$ from hand milking) and $68.07 \pm 2.83$ days respectively. The effect of parity and generation on doe weight after kidding was significant $(P<0.01)$ but the effect of generation $\times$ parity interaction was not significant $(P>0.05)$. Heritability estimates from sire and dam component for birth weight, weight at $3,6,9,12$ months of age and litter size were $0.92,0.48,0.34,0.45,0.88$ and 0.17 , respectively. Heritability estimates only from sire component for birth weight, weight at 3, 6, 9, 12 months of age and litter size were 0.05, 0.28, 0.77, 0.29, 0.18 and 0.15 , respectively. Repeatability estimates for birth weight, litter size, kidding interval and daily milk yield were $0.47,0.15,0.02$ and 0.49 , respectively.
\end{abstract}

Keywords: Black Bengal goat, Performance traits, Heritability, Repeatability

\section{Introduction}

The Black Bengal goat is a famous goat breed in the world. It is well known for high fertility, fecundity and excellent skin quality. Goat is well recognized as a tool of poverty alleviation. Goat meat is widely acceptable in our country and has a good market share, but it's milk has only a very small market share and has been consumed more as a medicine than as food (Son, 1999).

The goal of a livestock system including goats is to produce a quantity of quality products with maximum efficiency. A component in achieving this goal is to improve goat genetically in the areas of quantity, quality and efficiency. Genetic improvement can be achieved by selection. For example, over three years of constant selection, genetic base of Boer goats has become stable with improved adaptability (www.igagoatworld.org/publication/proceeding/abstract11.PDF). Since 1998, Bangladesh Livestock Research Institute has been attempted to improve Black Bengal goat through selective breeding. This Institute has produced many superior bucks, which have been playing great role in improving local goats in many areas of Bangladesh. The potential of genetic improvement of the trait of interest is largely dependent on it's heritability value and genetic relationship with other traits of economic importance upon which some selection pressure may be applied. Information on heritability is essential for planning efficient breeding programmes, and for prediction of response to selection (Falconer, 1989).

Estimates of heritability and repeatability are lacking for productive and reproductive traits of Black Bengal goat. To date only limited published information on heritability estimates on some productive and reproductive traits (Amin, 2000), growth performance (Mia et al.,1993; Husain et al., 1996a; Husain et al. 1996b cited by Amin, 2000), growth and reproductive performance (Chowdhury et. al., 2002; Ali et al., 1973; Shamsuddin et al. 2000;), heritability estimates on some economic traits (Ali and Hasnath, 1977), breed differentiation (Faruque et al., 1987) have been accomplished in Bangladesh. 
In order to guide practical breeding work, the genetic parameters should be estimated. This paper analyzed related breeding activities in Goat Breeding Farm of the Bangladesh Livestock Research Institute in last four years, and estimated the heritability and repeatability of some productive and reproductive traits, providing a scientific evidence for breed selection on this farm.

\section{Materials and Methods}

\section{Animal and data used}

The data used in the experiment were from the "Improvement of Black Bengal goat through selective breeding" project and then continuation project "Improvement of Black Bengal goat through selective breeding, improved feeding and management practices" project conducted at Bangladesh Livestock Research Institute, Savar, Dhaka. Ninety elite pre-pubertal Black Bengal does and 15 bucks (both foundation stocks) were collected from different parts of Bangladesh. Selection was mostly based on phenotypic characteristics viz. body size, conformation, weight for age, their ancestral history on production and reproduction and also on dam performance. Twinning and triplets kidding of dam was also considered for female selection. A total of 120 does of different generations ( $70=$ foundation stock, $45=$ First generation and $5=$ Second generation) and 20 bucks (15=Foundation stock and 5=First generation) were obtained to study the following performances: birth weight of male kids, birth weight of female kids, age and weight at first heat, age and weight at first kidding, number of service per conception (SPC), gestation length (GL), litter size (LS), post-partum heat period (PPHP), kidding interval (KI), milk yield (MY), lactation length (LL).

\section{Management procedure}

Housing: Initially goats were kept in the wooden metabolic stall and also in the concrete floor. Saw dusts and rice straw were used as bedding material. Then in second phase of the project, goats were housed in permanent house with slated platform of $1 \mathrm{~m}$ above ground. All goats were kept separately according to sex and age groups to avoid random mating and correct data.

Breeding: A selective breeding programme was performed to improve the economically important traits. The sign of heat was observed with a buck in the morning. Female in estrous were mated with the buck naturally according to mating chart that has been planned previous.

Feeding and rearing system: Goats were allowed to graze for 8 hours (from 9 AM to 5 PM) with 1-hour rest (13:00 PM to 14:00 PM). Animal were given a concentrate mixture containing 17\% CP, $11 \mathrm{MJ} \mathrm{ME} / \mathrm{kg}$ DM provided twice daily in the morning and evening at the rate of 200,250 and $100 \mathrm{~g} / \mathrm{d} / \mathrm{head}$ respectively for does, bucks and kids.

Health care and diseases: Animals were vaccinated against PPR (Peste Des Petits Ruminants), anthelmantics were applied and dipped in $0.5 \%$ melatheon solution. Sick animals or kids, stunted growth, unthrifty condition, repeat breeding, severe skin diseases were culled from the flock.

Milking: Kid had free access to their mother for the whole day except during the night (8.00 PM to 6.00 AM). Hand milking was performed every morning at 6.00 AM to 8.00 AM. Besides kids were also bottle fed with goats' or cows' milk.

Record keeping: All the experimental animals were ear-tagged individually. Flock book, shed book, milking book, kid book, mating book, health book, feed book were used for record keeping. All the information about production and reproduction were recorded in an individual data sheet for each of the animal. Then all data were stored in computer for anlyses.

Season: The year was divided into 3 seasons. These were season-1 (March-June), season-2 (JulyOctober) and season-3 (November-February). 
Statistical analysis: As the number of animals in each class and sub-classes for different traits was not same, an orthogonal factorial analysis was done to investigate the differences between main effects, generation, parity, feeding level, interaction between generation $\times$ parity and interaction between generation $\times$ feeding levels. Data of this study were analyzed by using univariate GLM procedure of SPSS 9.0 for Windows (SPSS Inc.1998) computer program. Least-Significant Difference (LSD) tests were performed in order to compare different means when variance was significantly different (Snedecor and Cochran, 1980). The following statistical model measured the effect of generation, parity and effect of feeding level.

\section{Model:}

$Y_{i j}=\mu+\alpha_{i}+e_{i j}$

Here, $\mu=$ general mean; $\alpha_{i}=$ effect of generation $(I=1,2$ or 3 ) or parity ( $(=1,2,3,4,5,6$ or 7 ) or feeding level ( $i=1,2$ or 3$), e_{i j}=$ random error.

\section{Estimation of genetic parameters}

Heritability: Heritability values were estimated for live weights (at birth, 3, 6, and 9 months of age) and litter size. Data were adjusted for significant sex, litter size and parity effects following (Chowdhury et. al. 2002) before estimating variance components. Variance components were calculated using sire, dam and combined sire-dam groups according to the method of Becker (1964). Heritability from only sire group was also estimated according to Becker (1964).

\section{Model:}

$Y_{i j k}=\mu+\alpha_{i}+\beta_{i j}+e_{i j k}$

Where, $Y_{i j k}$ is the record of the $k^{\text {th }}$ progeny of the $j^{\text {th }}$ dam mated to the $i^{\text {th }}$ sire; $\mu$ is the common mean; $\alpha_{i}$ is the effect of the ith sire; $\beta_{\mathrm{ij}}$ is the effect of the $\mathrm{j}^{\text {th }}$ dam and $e_{\mathrm{ijk}}$ is the uncontrolled environmental and genetic deviations attributable to the individuals. The structure of the variance components is furnished below:

\section{Analysis of variance Table}

\begin{tabular}{|l|c|c|c|c|}
\hline Source of variation & d.f. & S.S. & M.S. & EMS \\
\hline Between sires & S-1 & $S_{S}$ & $M S_{S}$ & $\sigma^{2}{ }_{w}+k_{2} \sigma_{d}^{2}+k_{3} \sigma^{2}{ }_{S}$ \\
\hline Between dams within sires & D-S & $S_{D}$ & $M S_{D}$ & $\sigma^{2}{ }_{w}+k_{1} \sigma^{2}{ }_{d}$ \\
\hline Progeny within dams & n..-D & $S S_{W}$ & $M S_{W}$ & $\sigma^{2}{ }_{w}$ \\
\hline
\end{tabular}

$S=$ total number of sires; $D=$ total number of dams; $n . .=$ total number of progeny; $k_{1}=k_{2}=$ number of progeny per dam; $\mathrm{k}_{3}=$ number of progeny per sire

Estimating variance components: $\sigma^{2}{ }_{w}=M S_{W} \quad \sigma_{d}^{2}=\frac{(M S D-M S W)}{k_{1}}$

$$
\sigma_{s}^{2}=\frac{M S_{s}-\left(\sigma_{w}^{2}+k_{2} \sigma_{d}^{2}\right)}{k_{3}}
$$

Here, $\mathrm{k}_{1}=/ \mathrm{k}_{2}$ the coefficients $\mathrm{k}_{1}, \mathrm{k}_{2}$ and $\mathrm{k}_{3}$ have to be computed differently

$$
\begin{aligned}
& \mathrm{k}_{1}= \frac{n . .-\frac{\sum \sum n_{i j}^{2}}{n i .}}{D-S} \\
& \mathrm{k}_{2}=\frac{\frac{\sum \sum n_{i j}^{2}}{n i .}-\frac{\sum \sum n_{i j}^{2}}{n . .}}{S-1} \\
& \mathrm{k}_{3}=\frac{n . .-\frac{\sum n_{i .}^{2}}{n . .}}{S-1}
\end{aligned}
$$

Here, $n=$ total number of progeny; $n_{i j}=$ number of progeny per dam; $n_{i}=$ Number of progeny per sire; $S=$ number of sire and $D=$ number of dam 
Repeatability estimate was obtained as follows:

$$
\mathrm{R}=\frac{\sigma_{d}^{2}}{\sigma_{d}^{2}+\sigma_{e}^{2}}
$$

Repeatability were estimated for daily milk yield, litter size and kidding interval. Here, $\sigma^{2}{ }_{d}=$ Variance component of dam; $\sigma^{2}{ }_{e}=$ Residual error term; Repeatability was estimated according to (Becker, 1964).

\section{Results and Discussion}

Birth weight of kid: Birth weight of kid as affected by rearing system, season, generation, parity and generation $\times$ parity interaction is shown in Table 1,2 and 3 respectively. Birth weight was highest $(P<0.10)$ in intensive rearing system $(1.49 \pm 0.13 \mathrm{~kg})$ and lowest $(1.28 \pm 0.11 \mathrm{~kg})$ in semi-intensive rearing system (Table 1). There were no significant effects of season (Table 2 ) on birth weight of kids, but it was affected $(P<0.10)$ by rearing system (Table 1$)$.

Birth weight of male kids was significantly $(P<0.001)$ affected by parity \& generation, but generation $x$ parity interaction effect was not significant $(P>0.05)$ (Table 3$)$. Whereas, birth weight of female kids was not affected $(P>0.05)$ by parity, generation and generation $x$ parity interaction. Many authors (Husain, 1999; Amin et al. 2001) reported that male kid has higher birth weight than female kids. Surprisingly in this study, overall birth weight was observed as $1.37 \pm 0.039 \mathrm{~kg}$ and $1.37 \pm 0.10 \mathrm{~kg}$ respectively for male and female kid (Table 3). Average birth weights of Black Bengal kids were $\overline{1} .03$ and $0.93 \mathrm{~kg}$ for male and female in Bangladesh (Husain, 1993) and 1.13kg in India (Acharya, 1988 and Singh, 1994), which was much lower than the present study. Acharya (1988) reported that year of birth, season, type of birth, parity, age and weight of dam at kidding significantly affect birth weight. Within breed differences are influenced partly by genetic factors but largely by variation within the environment. The environment specially includes nutrition, health and adult weight of the dam but not the age of the dam (Prasad et al. 1971; Devendra and Burns, 1983). Chowdhury et. al. (2002) reported that heavier birth weight indicate better environment especially nutrition and health. Birth weight was not affected by the litter type, which is similar to as previous observation (Chowdhury et. al. 2002). However, birth weight of male kid was significantly $(\mathrm{P}<0.001)$ affected by generation and parity (Table 3$)$.

Table 1. Effect of rearing system on productive and reproductive performance of Black Bengal goat (Generation-1, $1^{\text {st }}$ parity)

\begin{tabular}{|l|c|c|c|}
\hline \multirow{2}{*}{ Parameter } & Intensive & Semi-intensive & Probability \\
\cline { 2 - 4 } & Mean \pm SE & Mean \pm SE & \\
\hline Birth weight $(\mathrm{kg})$ of kids & $1.49 \pm 0.13$ & $1.28 \pm 0.11$ & $\mathrm{P}<0.10$ \\
\hline Service per conception & $1.0 \pm 0.28$ & $1.2 \pm 0.23$ & $\mathrm{NS}$ \\
\hline Gestation length (d) & $143.0 \pm 1.71$ & $142.8 \pm 1.4$ & $\mathrm{NS}$ \\
\hline Litter size & $1.5 \pm 0.16$ & $1.06 \pm 0.13$ & $\mathrm{P}<0.05$ \\
\hline Post-partum heat period (d) & $38 \pm 6.61$ & $33.1 \pm 5.4$ & $\mathrm{NS}$ \\
\hline Age at first heat (d) & $138.83 \pm 15.38$ & $197.82 \pm 12.58$ & $\mathrm{NS}$ \\
\hline Weight at first heat $(\mathrm{kg})$ & $9.62 \pm 0.76$ & $9.34 \pm 0.62$ & $\mathrm{P}<0.05$ \\
\hline Age at first kidding (d) & $283.83 \pm 31.16$ & $370.26 \pm 25.48$ & $\mathrm{P}<0.05$ \\
\hline Weight at first kidding $(\mathrm{kg})$ & $18.91 \pm 0.67$ & $16.07 \pm 0.55$ & $\mathrm{P}<0.01$ \\
\hline Daily morning milk yield $(\mathrm{g})$ & $236.74 \pm 40.32^{*}$ & $227.23 \pm 32.97{ }^{*}$ & $\mathrm{NS}$ \\
\hline Lactation length (d) & $48.83 \pm 10.86$ & $61.87 \pm 8.88$ & $\mathrm{NS}$ \\
\hline
\end{tabular}

NS $>0.05$

Kid had free access to their mother for over the 24 hours 
Table 2. Effect of season on productive and reproductive performance of Black Bengal goat

\begin{tabular}{|l|c|c|c|c|}
\hline \multicolumn{1}{|c|}{ Parameter } & Season-1 & Season-2 & Season-3 & \multirow{2}{*}{ Probability } \\
\cline { 2 - 5 } & Mean \pm SE & Mean \pm SE & Mean \pm SE & \\
\hline Birth weight $(\mathrm{kg})$ of kids & $1.36 \pm 0.1$ & $1.38 \pm 0.18$ & $1.15 \pm 0.14$ & $\mathrm{NS}$ \\
\hline Service per conception & $1.37 \pm 0.12$ & $1 \pm 0.4$ & $1.8 \pm 0.31$ & $\mathrm{NS}$ \\
\hline Gestation length (d) & $142.37 \pm 1.35$ & $142.83 \pm 2.42$ & $143.8 \pm 1.87$ & $\mathrm{NS}$ \\
\hline Litter size & $1.37 \pm 0.1$ & $1 \pm 0.23$ & $1 \pm 0.17$ & $\mathrm{NS}$ \\
\hline Post-partum heat period (d) & $41.5 \pm 5.22$ & $31.0 \pm 9.35$ & $25.4 \pm 7.24$ & $\mathrm{NS}$ \\
\hline Age at first heat (d) & $152.29^{\mathrm{b}} \pm 12.16$ & $216.16^{\mathrm{a}} \pm 21.75$ & $193.2^{\mathrm{a}} \pm 16.85$ & $\mathrm{P}<0.01$ \\
\hline Weight at first heat $(\mathrm{kg})$ & $9.21 \pm 06$ & $9.47 \pm 1.07$ & $9.64 \pm 0.83$ & $\mathrm{NS}$ \\
\hline Age at first kidding (d) & $331.41 \pm 24.63$ & $368.33 \pm 44.07$ & $365.4 \pm 34.14$ & $\mathrm{NS}$ \\
\hline Weight at first kidding (kg) & $18.27^{\mathrm{a}} \pm 0.53$ & $15.16^{\mathrm{b}} \pm 0.96$ & $16.32^{\mathrm{b}} \pm 0.74$ & $\mathrm{P}<0.01$ \\
\hline Daily morning milk yield (g) & $259.04 \pm 31.87^{*}$ & $198.44 \pm 57.02^{*}$ & $230.71 \pm 44.17^{*}$ & $\mathrm{NS}$ \\
\hline Lactation length (d) & $51.16 \pm 12.03$ & $66.5 \pm 15.36$ & $61.0 \pm 11.89$ & $\mathrm{NS}$ \\
\hline
\end{tabular}

NS > 0.05; Kid had free access to their mother for over the 24 hours; Season-1=March to June; Season-2 = July to October; Season-3 = November to February

Service per conception: Rearing system and season had no significant effect on number of service per conception (Table 1 and 2). Average number of services required for each successful conception was 1.16 \pm 0.19 . This result was almost similar to the findings of Garci et. al. (1996), Amin et al. (2001) and Faruque et al. (2002).

Gestation length: Parity, generation, rearing system, season, and parity $\times$ generation interaction had no significant $(p>0.05)$ effect on gestation length. Average gestation length observed in this trial was $143.33 \pm 0.68$ days. West African Dwarf goats have been reported to have gestation length of $141.3 \pm 4.7$ days (Otchere and Nimo, 1975) and 146.2+2.7 days (Montsma et al. 1981). Gupta et al. (1964) reported slightly high (145 days) gestation length for Black Bengal. It has been suggested that short gestations may be characteristic of small and dwarf breeds of goat. Gestation length was not affected $(P>0.05)$ by the generation, which, were $144 \pm 0.82,143 \pm 01.21$ and $141 \pm 3.37$ days respectively for foundation stock, $1^{\text {st }}$ and $2^{\text {nd }}$ generation.

Post- partum estrus interval (PPEI): The effects of rearing system, season, parity, generation, and generation $x$ parity interaction is shown in Table 1,2 and 3. PPEI were not significant $(P>0.05)$. The overall mean of $28.53+2.95$ days was lower than that reported by Husain, (1993); and Singh et al. (1987) whose values were $77.29 \pm 1.14$ and $105.8 \pm 10.80$ days, respectively. The PPEI of Black Bengal goat found to be $27.86 \pm 1.94,27.07 \pm 4.46$ and $37.0 \pm 23.62$ days respectively for foundation stock, Ist generation and $2^{\text {nd }}$ generation. But higher PPEI in Black Bengal goat of 125 days for the Ist generation and 70 days for the $2^{\text {nd }}$ generation has reported by Amin et al. (2001).

Age at first heat and weight at first heat: Effect of rearing system, and season on age and weight at first heat is shown in Table 1 and 2 respectively. Although not significant, intensive system (139 d) of rearing reduced the age at $1^{\text {st }}$ heat by 59 days compared to that of semi-intensive (198 d). The effects of season and feeding level on age at first heat were significant $(P<0.01)$ but rearing system did not affect $(P>0.05)$ the age at first heat. Age at first heat range between 123-294 days with an average of $186.02 \pm 10.52$ days which is lower than that of $241.23 \pm 15.18$ days observed in randomly bred Black Bengal goat (Amin, 2000). It has been reported that with better management and care of female kids, small and dwarf Indian breeds attain puberty as early as 150 (range: 150-437) days (Ali et al. 1973; Prasad, 1974; Rahman et al. 1977; Mukundan, 1980 cited by Husain, 1993). Live weight at first estrus was significantly $(P<0.05)$ affected by rearing system but the effect of season and feeding level on weight at first estrus was not significant $(P>0.05)$. Weight at first heat varies from 9.2 to $18.0 \mathrm{~kg}$ in some small and dwarf breeds (Ali et al. 1973, Mukundan, 1976 and 1980). The average live weight at first estrus in first generation was $9.4 \pm 0.52 \mathrm{~kg}$, which is almost similar to the result of Amin (2000) for random bred Black Bengal goat. Early maturity signifies the character inherited from Black Bengal goats. 
Table 3. Effect of parity, generation and generation and parity interaction on productive and reproductive performances of Black Bengal goat

\begin{tabular}{|c|c|c|c|c|c|c|c|}
\hline \multirow[t]{2}{*}{ Parameter } & \multirow[t]{2}{*}{ Parity } & \multirow{2}{*}{$\begin{array}{c}\text { Foundation stock } \\
\text { Mean } \pm \text { SE }\end{array}$} & \multirow{2}{*}{$\begin{array}{c}\text { Generation-1 } \\
\text { Mean } \pm \text { SE } \\
\end{array}$} & \multirow{2}{*}{$\begin{array}{c}\text { Generation-2 } \\
\text { Mean } \pm \text { SE } \\
\end{array}$} & \multicolumn{3}{|c|}{ Probability } \\
\hline & & & & & $\mathrm{Pa}$ & $\mathrm{Ge}$ & $\mathrm{Pa} \times \mathrm{Ge}$ \\
\hline \multirow[t]{7}{*}{ Post partum heat period (d) } & 1 & $32.31 \pm 5.42$ & $32.34 \pm 4.92$ & $37.0 \pm 23.6$ & NS & NS & NS \\
\hline & 2 & $42.18 \pm 3.34$ & $23.84 \pm 6.55$ & & & & \\
\hline & 3 & $24.97 \pm 3.56$ & $25.0 \pm 10.56$ & & & & \\
\hline & 4 & $28.4 \pm 3.99$ & & & & & \\
\hline & 5 & $19.21 \pm 4.46$ & & & & & \\
\hline & 6 & $20.08 \pm 6.82$ & & & & & \\
\hline & 7 & & & & & & \\
\hline \multirow[t]{6}{*}{ Kidding interval (d) } & 2 & $195.41 \pm 5.56$ & $205.11 \pm 9.08$ & & NS & NS & NS \\
\hline & 3 & $189.93 \pm 5.56$ & $174.0 \pm 12.19$ & & & & \\
\hline & 4 & $170.02 \pm 6.17$ & $176.0 \pm 22.26$ & & & & \\
\hline & 5 & $189.29 \pm 6.61$ & & & & & \\
\hline & 6 & $172.81 \pm 8.22$ & & & & & \\
\hline & 7 & $158.5 \pm 27.26$ & & & & & \\
\hline \multirow[t]{7}{*}{ Gestation length (d) } & 1 & $146.05 \pm 1.58$ & $143.66 \pm 1.08$ & $141.25 \pm 3.37$ & NS & NS & NS \\
\hline & 2 & $146.04 \pm 1.34$ & $142.33 \pm 1.58$ & & & & \\
\hline & 3 & $145.42 \pm 0.98$ & $143.0 \pm 2.13$ & & & & \\
\hline & 4 & $144.51 \pm 1.08$ & $143.0 \pm 3.89$ & & & & \\
\hline & 5 & $142.11 \pm 1.15$ & & & & & \\
\hline & 6 & $143.09 \pm 1.43$ & & & & & \\
\hline & 7 & $139.5 \pm 4.76$ & & & & & \\
\hline \multirow[t]{7}{*}{ Male kid birth weight $(\mathrm{kg})$} & 1 & $1.14^{\mathrm{bc}} \pm 0.05$ & $1.43 \pm 0.07$ & $1.39 \pm 0.13$ & $* * *$ & $* * *$ & NS \\
\hline & 2 & $1.29^{\mathrm{bc}} \pm 0.05$ & $1.4 \pm 0.08$ & & & & \\
\hline & 3 & $1.19^{c} \pm 0.05$ & $1.53 \pm 0.13$ & & & & \\
\hline & 4 & $1.44^{\mathrm{ab}} \pm 0.06$ & $1.73 \pm 0.22$ & & & & \\
\hline & 5 & $1.58^{\mathrm{a}} \pm 0.06$ & & & & & \\
\hline & 6 & $1.58^{\mathrm{a}} \pm 0.08$ & & & & & \\
\hline & 7 & $0.75^{\mathrm{c}} \pm 0.31$ & & & & & \\
\hline \multirow[t]{7}{*}{ Female kid birth weight $(\mathrm{kg})$} & 1 & $1.04 \pm 0.14$ & $1.22 \pm 0.14$ & & NS & NS & NS \\
\hline & 2 & $1.41 \pm 0.14$ & $1.24 \pm 0.29$ & & & & \\
\hline & 3 & $1.16 \pm 0.16$ & $1.35 \pm 0.29$ & & & & \\
\hline & 4 & $1.42 \pm 0.18$ & $1.85 \pm 0.63$ & & & & \\
\hline & 5 & $1.41 \pm 0.19$ & & & & & \\
\hline & 6 & $1.41 \pm 0.23$ & & & & & \\
\hline & 7 & $1.55 \pm 0.66$ & & & & & \\
\hline \multirow[t]{7}{*}{ Milk yield $(\mathrm{g} / \mathrm{d})$} & 1 & $293^{\mathrm{a}} \pm 22.7$ & $259^{\mathrm{b}} \pm 24.06$ & $218^{\mathrm{b}} \pm 69.1$ & * & $* * *$ & $* * *$ \\
\hline & 2 & $344 \pm 21.07$ & $275 \pm 34.5$ & & & & \\
\hline & 3 & $459 \pm 21.9$ & $256 \pm 43.7$ & & & & \\
\hline & 4 & $535 \pm 25.7$ & $185 \pm 97.7$ & & & & \\
\hline & 5 & $419 \pm 24.01$ & & & & & \\
\hline & 6 & $327 \pm 31.7$ & & & & & \\
\hline & 7 & $489 \pm 138.2^{*}$ & & & & & \\
\hline \multirow[t]{7}{*}{ Lactation length (d) } & 1 & $71.82 \pm 3.91$ & $64.75 \pm 4.09$ & & NS & ** & NS \\
\hline & 2 & $83.4 \pm 3.66$ & $60.5 \pm 5.79$ & & & & \\
\hline & 3 & $79.52 \pm 3.75$ & $54.6 \pm 7.32$ & & & & \\
\hline & 4 & $73.41 \pm 4.3$ & $67.5 \pm 16.37$ & & & & \\
\hline & 5 & $64.78 \pm 4.09$ & & & & & \\
\hline & 6 & $68.84 \pm 5.31$ & & & & & \\
\hline & 7 & $80.0 \pm 23.15$ & & & & & \\
\hline
\end{tabular}

NS > 0.05; abc values in the same row and same column different superscripts differ significantly.

$\mathrm{SE}=$ Standard Error; ${ }^{*}$ Kid had free access to their mother for over the 24 hours 
Age and weight at first kidding: Effect of rearing system and season on age and weight at first heat is shown in Table 1 and 2 respectively. Average age at first kidding was calculated to be 352.98 \pm 21.32 days. The effects of rearing system on age at first kidding and weight at first kidding were significant $(P<0.05)$ (Table 1). The age at first kidding in season 1, season 2, and season 3 were calculated to be $331.41 \pm 24.63,368.33 \pm 44.07$ and $365.4 \pm 34.14$ days respectively but did not differ significantly $(P>0.05)$ where as weight at first kidding was significantly $(P<0.01)$ affected by the season (Table 2$)$. Average age at first kidding was $283.83 \pm 31.16$ and $370.26 \pm 25.48$ days respectively for intensive and semi-intensive rearing system. Robinet (1973) reported some tropical goats may be conceived when only seven months old, while other do not attain first kidding until over two years of age (Singh and Singh, 1974). Whereas, in the present study doe under intensive rearing system conceived only 4.5 months and gave birth to their first kid at an average age of 9.5 months and live weight of $18.91 \pm 0.67 \mathrm{~kg}$. Chowdhury et. al. (2002) observed that doe under semi-intensive rearing system gave birth to their first kid at an average age of 13.5 months and live weight of $15.27 \mathrm{~kg}$. The variation of age at first kidding is partly environmental and partly genetic in origin. Thus, early age at first kidding reduces the cost of rearing replacements and increases economic returns, and also facilitates rapid genetic progress and is therefore, highly desirable (Devendra and Burns, 1983 cited by Husain, 1993).

Kidding interval: Kidding interval as affected by parity, generation and generation $\times$ parity interaction is shown in Table 3. Average kidding interval of $181.23 \pm 4.55$ days for this study is lower than $220.55 \pm 2.88$ days observed by Husain (1993) for Black Bengal goats and 220.90 days for Taiwan goats observed by Shi et al. (1996). Odubote (1996) observed the significant effects of parity, season and year on kidding interval in West African Dwarf goats. In this trial the effects of parity, generation and parity $\times$ generation interaction on kidding interval was not significant $(P>0.05)$ (Table 3$)$. In the present study very short kidding interval of Black Bengal goat indicate the complete seasonality of estrus occurrence which ultimately allow them to produce kid twice in a year (Husain, 1993).

Milk yield and lactation length: Effect of rearing system, season, parity, generation and generation $x$ parity interaction on age and weight at first heat is shown in Table 1, 2 and 3 respectively. The interaction effect of generation $x$ parity on milk yield was highly significant $(P<0.001)$ (table 3$)$ where as rearing system and season had no effect on milk yield (table 1and 2). The effect of generation was found to be prominent having similar trend with that of advancing parity. The overall daily morning milk yield and lactation length of $338.25 \pm 32.57 \mathrm{~g}$ and $68.07 \pm 2.83$ days of this study is higher than that reported by Husain (1993) as $241.1 \mathrm{~g} / \mathrm{d}$ and 32.2 days. The generation has significant effect $(P<0.01)$ on lactation length (table 3 ) but rearing system, season, parity and generation $\times$ parity interaction has no effect $(P>0.05)$ on lactation length (table $1,2,3)$. Milk production ability is mainly controlled by genetic properties within and between the breeds but environmental factors affect the total milk yield (Acharya, 1987). Among the environmental factors age of dam, year of kidding, season of kidding, lactation length and service period significantly affected the total milk yield (Devendra and Burns, 1983; Acharya, 1987 cited by Husain 1993).

Doe weight after kidding: Average doe weight after kidding was $23.56 \pm 0.41 \mathrm{~kg}$. The effects of parity and generation on doe weight after kidding were significant $(P<0.01)$ but the effect of generation $\times$ parity interaction was not significant $(P>0.05)$ (Table 5). Kid mortality is highly correlated with the dam weight at kidding. Dam less than $10 \mathrm{~kg}$ body weight had kid mortality of more than $87 \%$ which decreased ( $X 2$ =37.56; $\mathrm{P}<0.01$ ) exponentially with the increase in dam`s weight (Chowdhury et. al. 2002).

Litter size: Litter size as affected by rearing system and season is shown in Table 1 and 2 respectively. Litter size was significantly $(P<0.001)$ lower in the $1^{\text {st }}$ parity $(1.43 \pm 0.12)$ than in the $7^{\text {th }}$ parity $(3.00 \pm 0.45)$ (Table 5). Litter size was significantly $(P<0.05)$ higher in intensive than the semi-intensive system $($ Table 1). Litter size was non-significantly higher during season-1 (March to June). The significant effect of season obtained by Lopez et al. (1992) and Correa et al. (1994), where they observed that goat mated in summer had significantly larger litters than those mated in winter (2.03 VS. 1.41). In the present study average litter size of Black Bengal goat was 1.94 \pm 0.06 (Table 5), is similar to the result of Husain (1993) who found average litter size of $1.93 \pm 0.05$ for Black Bengal goat. Litter size increased linearly with parity as follows $Y=1.29+0.213 \times\left(r^{2}=0.81\right)$ where, $Y$ is the litter size; $X$ is the parity. 
Table 4. Effect of generation, parity and generation and parity interaction on litter size and doe weight after kidding of Black Bengal goat

\begin{tabular}{|c|c|c|c|c|c|c|c|}
\hline \multirow[t]{2}{*}{ Parameter } & \multirow[t]{2}{*}{ Parity } & \multirow{2}{*}{$\begin{array}{c}\begin{array}{c}\text { Foundation } \\
\text { stock }\end{array} \\
\text { Mean } \pm \text { SE } \\
\end{array}$} & \multirow{2}{*}{$\begin{array}{c}\text { Generation- } \\
1 \\
\text { Mean } \pm \text { SE }\end{array}$} & \multirow{2}{*}{$\begin{array}{c}\text { Generation- } \\
2 \\
\text { Mean } \pm \text { SE }\end{array}$} & \multicolumn{3}{|c|}{ Significance Level } \\
\hline & & & & & $\mathrm{Pa}$ & $\mathrm{Ge}$ & $\mathrm{Pa} \times \mathrm{Ge}$ \\
\hline \multirow[t]{7}{*}{ Doe weight after kidding (kg) } & 1 & $15.06^{\mathrm{e}} \pm 0.53$ & $16.83 \pm 0.63$ & $19.88 \pm 1.87$ & $* * *$ & ** & NS \\
\hline & 2 & $18.38^{d} \pm 0.56$ & $21.81 \pm 0.98$ & & & & \\
\hline & 3 & $21.56^{\mathrm{C}} \pm 0.59$ & $26.33 \pm 1.32$ & & & & \\
\hline & 4 & $27.09^{b} \pm 0.66$ & $26.71 \pm 2.41$ & & & & \\
\hline & 5 & $28.98^{\mathrm{b}} \pm 0.71$ & & & & & \\
\hline & 6 & $30.95^{a} \pm 0.89$ & & & & & \\
\hline & 7 & $29.2^{b} \pm 2.95$ & & & & & \\
\hline \multirow[t]{7}{*}{ Litter size } & 1 & $1.28 \pm 0.08$ & $1.10 \pm 0.13$ & $2.0 \pm 0.29$ & $* * *$ & NS & ** \\
\hline & 2 & $2.06 \pm 0.15$ & $1.83 \pm 0.15$ & & & & \\
\hline & 3 & $1.93 \pm 0.10$ & $2.50 \pm 0.20$ & & & & \\
\hline & 4 & $2.21 \pm 0.10$ & $2.33 \pm 0.37$ & & & & \\
\hline & 5 & $2.21 \pm 0.11$ & & & & & \\
\hline & 6 & $2.32 \pm 0.13$ & & & & & \\
\hline & 7 & $3.0 \pm 0.45$ & & & & & \\
\hline
\end{tabular}

NS $>0.05$

${ }^{\text {abcde }}$ Value in the same row different superscripts differ significantly. SE $=$ Standard Error

Seasonality of Kidding: Out of 643 kids born during experimental period, 350 were male and 293 were female. A sex ratio of 54.43: 45.57 (Male and Female) was not similar to the result of 50.4: 49.6 observed by Naidu (1992) in Deshi goats of Andhra Pradesh. Month wise frequency of kidding is presented Table 5. It could be seen from these results that the frequency of kidding was more during the months of March to June (Highest in March-13.33\%) and again during the months of July to September (Highest in August$11.59 \%$ ). Amble et al. (1962) reported higher kidding rate occurred from March to April and October to November in Jamunapari where as Chowdhury et.al. (2002) Showed that $47.64 \%$ kidding occurred during hot and wet months (July to September).

Table 5. Frequency of kidding during different months

\begin{tabular}{|c|c|c|c|c|c|}
\hline Months & $\begin{array}{c}\text { No. of does } \\
\text { kidded }\end{array}$ & Total kids born & Male & Female & $\begin{array}{c}\text { Percentage of } \\
\text { total kidding }\end{array}$ \\
\hline January & 17 & 37 & 21 & 16 & 4.92 \\
\hline February & 26 & 51 & 35 & 16 & 7.54 \\
\hline March & 46 & 86 & 41 & 45 & 13.33 \\
\hline April & 27 & 43 & 26 & 17 & 7.83 \\
\hline May & 27 & 54 & 30 & 24 & 7.83 \\
\hline June & 30 & 50 & 27 & 23 & 8.70 \\
\hline July & 34 & 66 & 33 & 33 & 9.85 \\
\hline August & 40 & 76 & 43 & 33 & 11.59 \\
\hline September & 26 & 49 & 26 & 23 & 7.54 \\
\hline October & 21 & 35 & 22 & 13 & 6.09 \\
\hline November & 22 & 46 & 25 & 21 & 6.38 \\
\hline December & 29 & 50 & 21 & 29 & 8.40 \\
\hline Total & 345 & 643 & 350 & 293 & 100 \\
\hline
\end{tabular}

Heritability $\left(\mathrm{h}^{2}\right)$ : Heritability $\left(\mathrm{h}^{2}\right)$ values were estimated for traits viz. live weight at (birth, 3 month, 6 month, 9 month and 12 month) and liter size. Values are summarized in Table 6. 
Live weight: Heritability of birth weight $(0.92)$ and 12 month weight $(0.88)$ are high, yet 3 month weight (0.48), 6 month weight $(0.34)$ and 9 month weight $(0.45)$ have moderate or high heritability. The lower estimates of heritability for birth weight in Black Bengal kids were reported by Guha et al. (1968); Moulick and Syrstad (1970), Singh et al. (1991a) and high estimate $(0.75 \pm 0.48)$ was reported by Ali and Hasnath (1977). Larger values for birth weight in other breeds of goats was observed by Oka et al. (1994), Mourad and Anous (1998), Tahir et al. (1995). This variation may be due to several factors such as heritability varies between breeds, places, flocks, sample size and method of estimation. Different environmental factors at different places, breeds, flocks and even year might increase the phenotypic variation. The high estimate of $h^{2} 0.92$ suggested that additive gene action or hereditary variation was high and individual selection and mating best to the best would be beneficial to improve birth weight.

Present estimate for 3 month live weight was little higher than that reported by Singh (1994) for Jamunapari and its crosses with Black Bengal but lower than those of Singh (1994) for Osmanabadi and Oka et al. (1994) for Australian Feral goat. Heritability for 3, 6, 9 and 12 months body weight was calculated as $0.48,0.34,0.45$ and 0.88 respectively. Roy et al. (1989) working on Jamunapari kids raised under semi-intensive conditions reported that heritability of body weight at 3 and 12 months were $0.43 \pm 0.15$ to $0.127 \pm 0.116$ respectively. Many estimates found to be very close with present estimates for 3, 6 and 9 months live weight. Except 12 month of them, Mourad and Anous (1998), Acharya (1988) may be referred. The highest value of $h^{2}$ for 9 month body weight was $1.00 \pm 0.14$ as reported by Acharya (1988). The birth weight and 1-month body weight are medium or high heritability traits (Hongping, china). In this study, the heritability of birth weight 3, 6, 9 and 12 months body weights are high. It indicates that genetic improvement of the offspring could be achieved by directly selecting the birth weight and lives weight traits.

Litter size at birth: Litter size of this study showed fairly which medium heritability (table 6 ) appears with those in West African Dwarf got (Odubote, 1996) and Boer goat (www.iga-goatworld.org/publication/ proceeding/abstract11.PDF). It is almost impossible to make direct genetic progress through directly selecting litter size as the trait because the litter size showed low heritability and sex-limited inheritance. The litter size not only affected by the maternal effect, but also influenced by the reproductive performance, feeding and management of the bucks (www.iga-goatworld.org/publication/proceeding/ abstract11.PDF). Therefore, to increase the kidding percentage of the whole herd not only depends on how to select the maternal goats, but to a large extent, on how to select bucks with high heritability. The faster growth rate and meat performance are the only indicators taken care of during selection bucks. Because litter size could not be seen on breeding bucks, how to accurately anticipate the genetic value of bucks is very important in selection of bucks and heritability improvement. Litter size is largely affected by environmental conditions.

Therefore, it is feasible to conduct early selection of breeding goats based on the birth weight and live weight traits.

Table 6. Partitioning of variance components and estimates of heritability $\left(\mathrm{h}^{2}\right)$

\begin{tabular}{|l|c|c|c|c|c|c|c|}
\hline \multirow{2}{*}{ Traits } & \multirow{2}{*}{ Sire } & \multirow{2}{*}{ Dam } & \multirow{2}{*}{ Residual } & $\mathrm{h}^{2}$ & \multirow{2}{*}{ Sire } & \multirow{2}{*}{ Residual } & $\mathrm{h}^{2}$ \\
& & & & From sire and dam & & & From sire \\
\hline Birth weight & -0.012 & 0.054 & 0.049 & 0.92 & 0.0012 & 0.093 & $0.05 \pm 0.08$ \\
\hline 3-month weight & 0.068 & 0.419 & 1.52 & 0.48 & 0.136 & 1.92 & $0.28 \pm 0.11$ \\
\hline 6- month weight & 1.08 & 4.26 & 25.56 & 0.34 & 1.12 & 4.64 & $0.77 \pm 0.56$ \\
\hline 9-month weight & 0.42 & 1.83 & 7.64 & 0.45 & 0.73 & 9.19 & $0.29 \pm 0.48$ \\
\hline 12-month & 14.6 & -10.3 & 5.38 & 0.88 & 0.83 & 17.6 & $0.18 \pm 0.47$ \\
\hline Litter size & 0.028 & 0.016 & 0.48 & 0.17 & 0.026 & 0.647 & $0.15 \pm 0.18$ \\
\hline
\end{tabular}

Repeatability (r): The repeatability estimate of progeny birth weight, litter size, kidding interval and milk yield of does was presented in Table 7 . Birth weight was found to show a fairly high repeatability. Repeatability estimate for birth weight was not available in the literature. However, low to moderate estimates of repeatability for birth weight were reported by (www.fao.org/wairdocs/ilri/x5473b/x 5473 boj.htm-52k) with the value of $0.20 \pm 0.18$. The repeatability estimate for litter size was 0.15 (Table 7) 
is lower than with the value reported by Odubote (1996) for West African Dwarf goat. As a result of the fairly moderate repeatability estimate, a single record of doe can be taken as a fair assessment of its potential. Systematic culling of unproductive animals may be the most important management practice to increase the litter size at birth (Odubote, 1996). Also selecting males for breeding from parents with poor fertility should be avoided. Since 1999, management system permitted culling of does with small litters. Repeatability estimate of 0.02 for kidding interval is low. This is not different from earlier report by Odubote (1996) and Odubote and Akinokun (1992).

The repeatability of daily milk yield estimated in this study was more or less similar to the estimates of 0.42 and 0.36 reported by Devendra and Burns (1983g) for 6 types combined and Beetal goats, respectively. However, the repeatability estimate for milk yield was high, which suggested that culling low producing does would improve average milk yield of the flock.

The repeatability estimates of reproductive traits were quite low which reflected on environmental variation. Therefore, improvement in these traits is possible by individual selection and improving management. Because the repeatability of a trait is not due to a change in the heredity, it is rather due to a change in the environment.

Table 7. Causal variance components and repeatability estimates of birth weight, litter size, kidding interval and milk yield

\begin{tabular}{|l|c|c|c|c|}
\hline Variance components & Birth weight & Litter size & Kidding interval & Daily milk yield \\
\hline Dam & 0.0442 & 0.092 & 1.26 & 0.025 \\
\hline Residual & 0.049 & 0.54 & 84.4 & 0.026 \\
\hline Repeatability $(r)$ & 0.47 & 0.15 & 0.02 & 0.490 \\
\hline
\end{tabular}

\section{Conclusion}

As it is already been established that the Black Bengal goat has got its excellence for the various productive and reproductive attributes, it is essential to improve this genetic resource. Improving the productivity of Black Bengal goat through selection and breeding requires long term breeding programme, which according to Mukherjee (2000) would require at least 10 years. But mating phenotypically best animals to the best with proper nutrition in this herd showed a favorable response in terms of birth weight and milk production. To some extent, reduction of post-partum heat period and kidding interval was also observed. Heritability for live weight and birth weights were high (0.34-0.92) interpreting that individual selection may be effective.

\section{References}

Acharya, R.M. 1987. Breeds of goats and research programmes for their improvement in India. Proc. IV International Conference on Goats, Brazil. Vol 1. pp 772-805.

Acharya, R.M. 1988. Goat breeding and meat production. Goat meat production in India. Proceedings of the Workshop held in Tando Jam, Pakistan, Edited by C. Devendra, 1988.

Acharya, R.M. 1988. Goat breeding and meat production. In: Goat meat production in Asia. Proc. workshop held in Tando Jam, Pakistan, 13-18 March, 1988. pp. 14-19.

Ali, S.Z. and Hasnath, M.A.. 1977. Heritability estimates of birth weight of Black Bengal kids at the Bangladesh Agricultural University Goat Breeding Project. Ind. Vet. J. 54 (8):632-637.

Ali, S.Z., Hoque, M.M. and Hasnath, M.M. 1973. A study on the growth and reproductive performance of Black Bengal goats under farm conditions. Indian Veterinary Journal, 50:438-440.

Amble, V.N., Khandekar, N.C. and Grag, J.N. 1962. Statistical studies on breeding data of Beetal goats. I.C.A.R. Research Series No. 38. Indian Council of Agricultural Research. 70.

Amin, M.R., Husain, S.S. and Islam, A.B.M.M. 2001. Reproductive peculiarities and litter weight in different genetic groups of Black Bengal does. Asian-Australasian Journal of Animal Science. 14(3): 297-301. 
Amin, M.R. 2000. Genetic Improvement of Production Traits in Bangladesh Goats BY Selective Breeding and Crossbreeding. A Ph.D. Thesis, Department of Animal Breeding and Genetics, Bangladesh Agricultural University, Mymensingh.

Becker, A.W. 1964. Manual of procedures in quantitative genetics. Washington State University, Pullman, Washington.

Chowdhury, S.A., Bhuiyan, M.S.A. and Faruk, S. 2002. Rearing Black Bengal goat under Semi-intensive management. 1. Physiological and reproductive performances. Asian-Aus. J. Anim. Sci. Voi 15, No. 4: 477-484.

Correa, A., Avendano, L. and Padilla, R. 1994. Effect of two mating seasons on fertility and prolificacy of goat breeds in the Mexicali Valley. Cuban Journal of Agricultural Science, 28 (3): 317-320.

Das, S.M., Rege, J.E.O. and Mesfin Shibre. Phenotypic and genetic parameters of growth traits of Blended goats at Malya, Tanzania. (www.fao.org/wairdocs/ilri/x5473b/x5473boj.htm-52k)

Devendra, C. and Burns, M. 1983. Goat production in the Tropics. Commonwealth Agricultural Bureaux, U.K.

Devendra, C. and Burns, M. 1983g. Genetic improvement. In: Goat Production in the tropics. Commonwealth Agricultural Bureaux, U.K. pp 132-144.

Falconer D.S. 1989. Introduction to Quantitative Genetics. $3^{\text {rd }}$ edition. Longman Group Ltd. England.

Faruque, M.O., Hasnath, M.A.., Mostafa, K.G., Okada, I., Amano, T., kurosawa, Y., Ota, K. and Namikawa, T. 1987. Conservation of livestook genetic resources in Bangladesh, Faculty of Applied Biological Sci. Hiroshima University, Japan. 2: 129-137.

Faruque, S., Husain, S.S., Rahman, M.M., Roy, B.K., Islam, M.N. and Islam, M.S. 2002. A study on the reproductive performance of does in different genetic groups under village condition. Online Journal of Biological Sciences 2(5) : 325-328.

Garci, B.O., Garcia, B.E., Bravo, J. and Bradford, E. 1996. Analysis of a crossbreeding trial with Criollo and imported goats. 6. other reproductive traits. Revista-de-la-Facultad-de-Agronomia, Universidad-del-Zulia. 13 (5): 597-609.

Guha, H., Gupta, S., Mukherjee, A.K., Moulick, S.K. and Bhattachrya, S. 1968. Some causes of variation in the growth rates of Black Bengal goats. Ind. J. Vet. Sci. and Anim. Husb. 38 (3):269-278.(ABA 37, 2666)

Gupta, S., Som, T.L. and Bhattacharyya, S. 1964. Studies on gestation length in Black Bengal goats. Indian Veterinary Journal, 41: $668-672$.

Hongping, Z. Estimation of genetic parameters of Boer goat reproductive traits. (Sichuan Agricultural University, Ya`an, Sichuan 625000 , China). (www.iga-goatworld.org/publication/proceeding/abstract11.PDF)

Husain, S.S. 1993. A study on the productive performance and genetic potentials of Black Bengal goats. A Ph.D. Thesis, Bangladesh Agricultural University, Mymensingh, pp. 3-108.

Husain, S.S. 1999. Sustainable genetic improvement of economic traits of Black Bengal goats through selective and cross breeding. Bangladesh Agricultural University Research Progress. 10, 72-80.

Husain, S.S., Horst, P. and Islam, A.B.M.M. 1996a. Study on the growth performance of Black Bengal goats in different periods. Small Ruminant Research, 21:165-171.

Husain, S.S., Horst, P. and Islam, A.B.M.M. 1996b. Phenotypic selection on the improvement of growth performance of Black Bengal kids. Asian Australasian Journal of Animal Science, 9 (2):149-153.

Lopez, J.L., Capote, J., Fresno, M. and Mayans, S. 1992. Prolificacy of Canary Island Goats In: Proceedings of International Symposium on Goat Breeding in Arid Zones, Coquimba, Chile, 23026 Oct. 1990. Terra-Arida. 1992, 11:99-104.

Mata, J., Darmanin, N., Camacho, A. and Camacho, M.E. 1998. Prolificacy in the Canary goat group. Animal Breeding Abstracts, 66 (8):725.

Mia, M.M., Ali, A. and Howlider, M.A.R. 1993. Growth performance of Black Bengal, Barbari, Anglo-Nubian and Barbari $\times$ Black Bengal goats.Indian. J. Anim. Sci. 63(11): 1214-1215

Montsama, G., Groen, A. and Hofs, P. 1981. Efficiency of meat production in dwarf goats. In intensive animal production in develop countries. Thames Ditton, U.K.; British Society for Animal Production, 429-434. Occasonal publication, British Society of Animal Production, 4.

Moulick, S.K. and Syrstad, O. 1970. Genetic and environmental causes of variation in birth weight of Black Bengal goat. J. Agril. Sci., U.K. 74:409 (ABA 39, 648).

Mourad, M. and Anous, M.R. 1998. Estimates of genetic and phenotypic parameters of some growth traits in Common African and Alpine crossbred goats. Small Ruminant Research, 27 : 197 - 202.

Mukherjee, T.K. 2000. Consultency report on Goat and Sheep production. Bangladesh Livestock Research Institute, Savar, Dhaka. 
Mukundan, G. 1976. Goat breeding (milk). Progress report at Karala Agricultural University. Proceeding of the $2^{\text {nd }}$ workshop on AICRP on goat breeding, NDRI, Karala, India.

Mukundan, G. 1980. Genetic studies on some economically important production characteristics of Malabari breed of goats and its exotic crosses. Ph. D. Thesis, Rohikhand University, India.

Nahardeka, N., Das, D., Goswami, R.N., Roy, T.C. and Gogoi, P.K. 1995. Reproductive performance of Assam local goats and their crossbreds with Beetal. Indian Journal of Small Ruminants, 1 (1): 8-14.

Naidu, M.M. 1992. Kidding trend in deshi goats of Andhra Pradesh. Indian Veterinary Journal. 69. February, : 187-188.

Odubote, I.K. 1996. Genetic parameters for litter size at birth and kidding interval in the West African Dwarf goats. Small Ruminant Research $20: 261-265$.

Odubote, I.K. and Akinokun, J.O. 1992. Estimates of genetic parameters for economic traits in West African Dwarf Goat. Niger. J. Anim. Prod., $19: 114-119$.

Oka, I.L., Pattie, W.A. and Restail, B.J. 1994. Phenotypic and genetic parameters of live weights and growth rates in Australian feral goats. Proc. $7^{\text {th }}$ AAAP Animal Science Congress, BALI, Indonesia, 11-16 July 1994. Vol. 2 (ABA 64, 5413).

Otchere, E.O. and Nimo, M.C. 1975. Observations on the reproductive behaviour in the West African dwarf goat. Ghana Journal of Agricultural Science 8(3) : 187-190 (ABA 47, 2364).

Prasad, S.P. 1974. Studies on some aspects of reproduction in Barbari nannies. Ph.D. Thesis, Agra University, Uttar Pradesh, India.

Prasad, S.P., Roy, A. and Pandey, M.D. 1971. Influence of age, body weight, parity and season on the reproductive performance of Barbari goat. (ABA 41, 3512).

Rahman, A., Hossain, A., Ahmed, M.U. and Sen, M.M. 1977. Studies on some reproductive performances and biometry of female genital tract of Black Bengal goat. Ind. J. Anim. Sci. 47: 724-725.

Robinet, A.H. 1973. The Maradi goat and goat breeding in Nigeria, (ABA 42, 1646).

Roy, R., Prakash, B. and Khan B.U. 1989. Genetic and non-genetic sources of variationfor growth in Jamunapari kids. Ind. J. Anim. Sci. $59: 874-877$

Ruvuna, F.T.C. Cartwright, H. Blackburn, Okeyo, M. and Chema, S. 1988. Gestation length, birth weight and growth rates of purebred indigenous goats and their crosses in Kenya. Journal of Agricultural Science, 3 (2): 363-368.

Shamsuddin, M., Amiri, Y. and Bhuiyan, M.M.U. 2000. Characteristics of buck semen with regard to ejaculate number, collection intervals, diluents and preservation periods. Reprod. Dom. Anim. 35: 53-57.

Shi, Y.C., Huang, Y.H. and Liu, L.C. 1996. Indigenous domestic animals-characteristics of Taiwan Native goats. Journal of Taiwan Livestock Research, 29 (4): 437-451.

Singh, B.B. and Singh, B.P. 1974. Performance of Jamunapari goats. Indian Journal of Veterinary Science, 51: $326-332$ (ABA 43 2388).

Singh, D.K. 1994. Improvement of goat production in India. World Agriculture. Sterling Publication Ltd. London. pp. 78-81.

Singh, D.K., Singh, C.S.P. and Jha, K. 1991 a. Post-weaning survivability in kids under village conditions. Indian Journal of Animal Sciences, 61 (2): 228-229.

Singh, D.K., Singh, C.S.P. and Singh, L.B. 1987. Reproductive traits of Black Bengal goats. Indian Journal of Animal Sciences, 57 (6): 605-608.

Son, Y.S. 1999. Production and uses of Korean native Black goat. Small Ruminant Research, 34: 303-308.

Tahir, M., Younas, M., Raza, S.H., Lateef, M., Iqbal, A. and Raza, P.N. 1995. A study on estimation of heritability of birth weight and weaning weight of Teddy goats kept under Pakistani conditions. Asian-Australasian Journal of Animal Sciences, Vol. 8 (no. 6) : $595-597$

Verma, R.R.P., Singh, B.K., Singh, M.P. and Singh, B. 1991. Factors affecting reproductive performance in Black Bengal goats. Indian Veterinary Journal, 68 (1): 235-239. 